\title{
A Comprehensive Analysis of Ready to Eat Snack Food
}

\author{
Reeta Mishra*, Y.D. Mishra, B.P.S. Raghubanshi and P.P. Singh \\ RVSKVV- Krishi Vigyan Kendra, Morena (M.P.), India \\ Directorate of Extension Services, RVSKVV-Gwalior (M.P.), India \\ *Corresponding author
}

\begin{tabular}{|l|}
\hline K e y w o r d s \\
$\begin{array}{l}\text { Soybean, Pearl millet, } \\
\text { Ready to eat snack food, } \\
\text { Fortification, Sensory } \\
\text { characteristics }\end{array}$ \\
\hline Article Info \\
\hline $\begin{array}{l}\text { Accepted: } \\
\text { 22 June } 2018 \\
\text { Available Online: } \\
\text { 10 August } 2018\end{array}$ \\
\hline
\end{tabular}

Ready to eat snack food (sattu) was enriched with soy and pearlmillet flour. Sattu were evaluated for nutrient and sensory characteristics. In nutrient estimation of sattu, moisture content was found maximum in treatment $\mathrm{C}$, while protein, fat, ash, calorie content and iron content was maximum in treatment $\mathrm{D}$. The carbohydrate was found maximum in treatment $\mathrm{C}$ and calcium content was maximum in treatment $\mathrm{E}$. Best treatment was D among C, D and E. The soy and pearlmillet flours fortified sattu had good shelf life. The product is ready -to-eat so don't require much time for preparation. It is a compact source of energy and nutrients including protein, fat, iron, calcium etc. Organoleptic test of sattus showed that with regard to flavour and taste, body and texture, colour and appearance and overall acceptability, sensory characteristics of $\mathrm{D}$ were found to be the best. The other treatments $\mathrm{C}$ and $\mathrm{E}$ were also found acceptable. Sensory scores indicated high acceptability for fortified ready to eat snack food sattu samples. Protein and fat contents of sattu increased with increasing soy and pearl-millet fortifications. The implication of these results will be realized in designing protein- energy enriched products based on pearl millet and soy flours, especially for pearl-millet and soybean growing regions in the Morena district of Madhya Pradesh.

\section{Introduction}

Food based approaches aim at improving nutrition by increasing the availability and consumption of a nutritionally adequate and micronutrient rich diet made up from a variety of available foods. Food based approaches are recognized as an essential part of an urgently needed more comprehensive strategy to combat iron and other micronutrient deficiencies. Therefore, for solving the problem of deep-rooted food insecurity and malnutrition, dietary quality should be taken into consideration (Singh and Raghuvanshi, 2012).

Millets are considered as crop of food security because of their sustainability in adverse agroclimatic conditions (Ushakumari et al., 2004). These crops have substantive potential in broadening the genetic diversity in the food basket and ensuring improved food and nutrition security (Mal et al., 2010).

Absence of appropriate primary processing technologies to prepare ready-to-use or readyto-cook (RTC) products and also secondary as 
well as tertiary processing to prepare ready-toeat value added products have been the major limiting factors for their diversified food uses and better economic status (Malleshi, 2014).

Soybean is a unique crop with high nutritional value, providing $40 \%$ protein and $20 \%$ edible oil, besides minerals and vitamins. It is playing an important role in augmenting both the production of edible oil and protein. Soybean meal is used as protein supplement in human diet, cattle and poultry feed (Khanzada et. al. 2013). In addition, compared to other protein rich foods such as meat, fish, and eggs, soybean is by far the cheapest. The importance of soybeans and their products is primarily associated with their high nutritional quality especially with respect to protein and amino acids (Gandhi, 2009).

Pearlmillet and soybean are the major crops grown in Morena district of Madhya Pradesh. But the main use of above crops is only as feed and fodder in rural households. Pearlmillet has low protein content and limited in lysine. On the other hand, soy protein is rich in lysine but low in methionine and cystine. Therefore, combination of both will produce highly nutritious fortified products for farm women and their family members. Sattu is a roasted flour mixture of cereal and pulse combination and used as ready-to-eat snack food in most parts of India (Deshpande et al., 2004). Sattu has its own benefits for all age groups. The nutritional value of sattu can be enhanced by fortification and supplementation with a wide variety of protein, vitamin and mineral sources.

Hence, this work was designed to economically complement and fortify ready to eat snack food sattu by soy and pearl-millet flour and to study their nutritional and sensory characteristics and shelf life of sattu in LDPE bags at room temperature.

Materials and Methods

\section{Procurement of materials}

The seeds of soybean (Glycine max) were procured in a single lot from the Zonal Agriculture Research Station, Morena. The Bengal gram was procured from local market in a lot. The seeds cleaned of dust, cracked and broken seeds and other foreign materials were handpicked.

\section{Sample preparation}

Cleaned whole grains of soybean, wheat, pearlmillet and Bengal gram were separately moisture conditioned to obtain $30 \%$ moisture level in each of these samples. For this, samples were sprinkled with a predetermined quantity of water calculated based on their respective initial moisture contents (Figure 1). Each of these samples was then roasted in a hot sand bath at $180^{\circ} \mathrm{C}$, with continuous stirring, for about 10-12 min followed by their dehulling.

The dehulled samples were then mixed in the three selected proportions of soybean, wheat/pearlmillet and Bengal gram viz. C (10S:20W:70B), D (15S:15P:70B) and E (10S:10P:80B), respectively for sattu preparation. Samples thus prepared were ground and powdered so as to pass through ISS No. 30 sieve.

Sattu at different levels of incorporation were evaluated for their nutritional and sensory characteristics like color, taste, flavor, texture and overall acceptability by nine-point hedonic scale by a panel of 10 judges.

\section{Determination of shelf life}

The samples of soy sattu were filled in low density polyethylene (LDPE) packages and steel containers. The filled LDPE bags were sealed using heat-sealing machine while the 
sattu samples filled in metal container were closed with an airtight lid.

The LDPE packages, were withdrawn after 0 , 30, 45and 60days for analysis to determine shelf life of stored samples. Likewise, samples were also drawn from metal containers by opening its lid at same time intervals. The insect infestation and change in colour were observed visually. The storage period $0+$ two months was considered in view of the fact that such a shelf life should be adequate for a snack product packaged in small quantities and is consumed on a daily basis.

\section{Results and Discussion}

\section{Nutritional quality of fortified sattu}

The results of nutritional quality of fortified sattu (product C, D and E) are presented in Table 1. Moisture content of three types of ready mixes sattu ranged from 9.89 to 10.83 percent (Table 1). The results obtained in this study are in agreement with earlier workers (Rawat et al., 1994; Singh et al., 2006), who also reported that moisture content increased in soy-fortified products.

The protein content of ready mixes sattu varied from 18.65 to 20.19 percent. Maximum protein content was observed in sample D which was prepared from soybean and pearlmillet fortification at a level of $15 \%$.

Fat content of all sattu mixes were significantly different from each other and higher fat content observed in sample D. A range of 2.86 to 3.14 percent of mean values for ash content was observed in different types of sattu mixes. Crude fiber content ranged from 3.34 to 3.61 percent. Significantly higher fiber content was observed in type E. Energy values for product $\mathrm{C}, \mathrm{D}$ and $\mathrm{E}$ were 364.4, 370.95 and $367.3 \mathrm{kcal} / 100 \mathrm{~g}$, respectively.

The mineral content of sattu for iron and calcium were in the range of 5.52 to 5.98 and 173.6 to $189.8 \mathrm{mg} / 100 \mathrm{~g}$, respectively.

Among different sattu mixes, higher iron content was observed in type D followed by Type $\mathrm{C}$ and $\mathrm{E}$, which might be due to incorporation of higher level of soybean flour as soybean had $10.4 \mathrm{mg}$ iron/100g (Gopalan et al., 2000).

Calcium of different types of sattu ready mixes varied significantly with each other. Highest calcium content was observed in type $\mathrm{E}$, followed by type $\mathrm{D}$ and $\mathrm{C}$, respectively. Higher calcium content observed in D and $\mathrm{E}$ might be due to incorporation of pearlmillet.

Further, as the soy fortification increased, reduction in carbohydrate was observed. This might have happened since the soybean contains low carbohydrates. Increase in total minerals may be attributed to higher amount of minerals present in the soybean and pearlmillet.

Deshpande et al., (2004) have reported similar results for fortified foods developed for adoption at home and community level.

\section{Sensory evaluation of fortified sattu}

Nine-point hedonic scale was used to evaluate the acceptability of the products. The results of the nine-point hedonic scale for C, D and E products of sattu were presented in Table 3.

\section{Colour}

The mean sensory scores showed that there was a major difference among treatments $\mathrm{C}, \mathrm{D}$ and $\mathrm{E}$ (Table 2). The scores for colour ranged from 6.54 to 7.52. The highest was recorded for treatment $\mathrm{D}$ followed by $\mathrm{C}$ and $\mathrm{E}$. However colour scores increased slightly as the substitutes increased (Ugwuona, 2009). 
Fig.1 Flow - chart for preparation of ready to eat snack food (sattu)

Cleaning (Soybean, wheat/pearlmillet and Bengal gram)

Conditioning to $30 \%$ moisture (Each ingredient separately)

Roasting (Each ingredient separately)

Dehulling/ dehusking (Each ingredient separately)

Mixing of ingredients in selected proportions

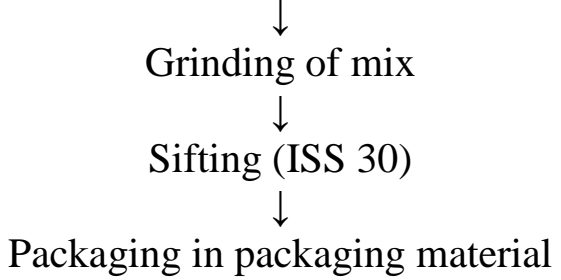

Table.1 Nutritional composition of fortified sattu

\begin{tabular}{|l|c|c|c|}
\hline \multicolumn{1}{|c|}{ Parameter } & C & D & E \\
\hline \% Moisture & 10.23 & 9.94 & 9.89 \\
\hline \% Crude fibre & 3.34 & 3.47 & 3.61 \\
\hline \% Ash & 2.86 & 3.14 & 3.09 \\
\hline \% Crude fat & 5.96 & 7.39 & 6.69 \\
\hline \% Crude protein & 18.65 & 20.19 & 19.16 \\
\hline \% Carbohydrate & 58.96 & 55.9 & 57.56 \\
\hline Energy (Kcal/100g) & 364.4 & 370.95 & 367.3 \\
\hline Iron $(\mathbf{m g} / \mathbf{1 0 0 g})$ & 5.3 & 5.98 & 5.52 \\
\hline Calcium (mg/100g) & 173.6 & 183.7 & 189.8 \\
\hline
\end{tabular}

*Significant difference

Table.2 Composite rating of fortified sattu

\begin{tabular}{|c|c|c|c|c|c|c|}
\hline Parameter & C & D & E & F-value & $\begin{array}{c}\text { Significant(S)/ } \\
\text { Non- } \\
\text { significant } \\
\text { (NS) }\end{array}$ & $\begin{array}{c}\text { CD 5 5 } \\
\text { level }\end{array}$ \\
\hline Color & 7.00 & 7.52 & 6.54 & 24.04 & $\mathrm{~S}$ & 0.436 \\
\hline Taste & 7.12 & 7.64 & 6.60 & 19.314 & $\mathrm{~S}$ & 0.516 \\
\hline Flavour & 6.92 & 7.44 & 6.60 & 12.836 & $\mathrm{~S}$ & 0.516 \\
\hline Texture & 7.12 & 7.60 & 6.80 & 15.012 & $\mathrm{~S}$ & 0.453 \\
\hline Overall & 7.24 & 7.92 & 6.62 & 33.03 & $\mathrm{~S}$ & 0.484 \\
\hline
\end{tabular}


Table.3 Rating of ready to eat snack product (sattu) moderately for preference by hedonic scale

\begin{tabular}{|c|c|l|c|c|c|}
\hline Products & Mean score & Preference & F-value & $\begin{array}{c}\text { Significant(S)/ Non- } \\
\text { significant (NS) }\end{array}$ & $\begin{array}{c}\text { CD at 5\% } \\
\text { level }\end{array}$ \\
\hline C & 7.34 & Like moderately & & & \\
\hline D & 7.92 & Like moderately & 50.09 & S & 0.472 \\
\hline E & 6.40 & Like slightly & & & \\
\hline
\end{tabular}

* Nine-point hedonic scale was used to evaluate consumer's acceptability of products

\section{Taste}

Major differences were observed among three types of prepared sattu. The highest sensory score was recorded for sample D (7.64) followed by sample $\mathrm{C}(7.12)$. The least was recorded for treatment $\mathrm{E}(6.60)$.

\section{Flavour}

All three sattu exhibited significant difference in regards to flavour component. The highest score was recorded for treatment D.

\section{Texture}

The mean texture scores ranged from 6.80 to 7.12. A major difference was observed among three. The highest score (7.60) was recorded for treatment $\mathrm{D}$.

\section{Overall acceptability}

The highest sensory score (7.92) was recorded for treatment $\mathrm{D}$ followed by treatment $\mathrm{C}$.

It shows that product $\mathrm{D}$ had highest scores, followed by product $\mathrm{C}$ and product $\mathrm{E}$. The difference among all the products was found to be significant $(\mathrm{P}<0.05)$.

These products were devoid of off flavour and possessed acceptable characteristics. The results are in accordance with Deshpande (1990) and Deshpande and Joshi (2001) who reported similar results while evaluating different products prepared as soy-blended snacks at domestic level.

\section{Storage and shelf life of sattu}

Packaging of prepared products is necessary to prevent contamination during transport and storage. Prepared sattu could be stored safely for 60 days in humid and warm conditions of storage in metal containers while the LDPE packages stored it safely for 30 days in warm conditions and 15 days in humid conditions.

Soybean and pearl-millet flour have high nutritive value. Sattu prepared from incorporation of soybean and pearl-millet was acceptable at incorporation level of $15 \%$.

Thus, soybean-pearlmillet ready to eat snack food may be helpful to increase intake of protein, fat and calories by improving the dietary intake of farm women and their family members. Hence, blend of soybean and pearlmillet incorporation has potential as an ingredient in healthy low cost nutritious ready to eat foods.

To improve the nutritional quality of cerealbased traditional diets in Morena district of Madhya Pradesh, the use of soybean as a protein supplement has often been suggested. Supplementation of pearl millet with soybean makes it nutritionally superior and produces acceptable food products for enhancement of nutritional status of farm women and their family members. 


\section{References}

Deshpande, S.D. (1990). Studies on some engineering aspects for processing and utilization of soybean. Ph.D. Thesis, Indian Institute of Technology, Kharagpur.

Deshpande, S.S. and Joshi, K.C. (2001). Soy sattu- paushtik evam swadishta bhojya padarth. Kheti Sansar, 6: 15.

Deshpande, S.S., Joshi, K.C., Bargale, P.C., Jha, K., Singh, V. and Varghese, S. (2004). Development, acceptability and shelf life studies on soy fortified maize sattu. Journal of Food Science \& Technology, 41(6): 674-678.

Gandhi, A.P. (2009). Quality of soybean and its food products. Central Institute of Agricultural Engineering, Bhopal462038(MP), India. International Food Research Journal, 16: 11-19.

Gopalan, C., Ramasastry, B. and Manian, S.C. (2000). Nutritive value of Indian foods, National Institute of Nutrition, Indian Council of Medical Research, Hyderabad, India.

Khanzada, S.R., Khanzada, M.S., Abro, G.H., Syed, T.S., Soomro, K., Khanzada, A. M., Anwar, S. and Shakeel, N. (2013). Relative resistance of soyabean cultivars against sucking insect pests. Pakistan Journal of Science, 65(2): 97 201.

Mal, B., Padulosi, S. and Ravi, S.B. (2010). Minor millets in South Asia: Learnings from IFAD-NUS Project in India and Nepal. Maccarese, Rome, Italy: Bioversity Intl., and Chennai, India: M.S. Swaminathan Research Foundation: pp.1-185.

Malleshi, N.G. (2014). Post-harvest processing of millets for value addition. http://isites.harvard.edu

/fs/docs/icb.topic868074., cited on 21.07.2014.

Rawat, A., Singh, G., Mittal, B.K. and Mittal, S.K. (1994). Effect of soy fortification on quality characteristics of chapaties. $J$ Food Sci. Technol., 31: 114 - 116.

Singh, G., Sehgal, S. and Kwatra, A. (2006). Sensory and nutritional evaluation of cake developed from blanched and malted pearl millet. J Food Sci Technol. 43 (5): $505-508$.

Singh, P. and Raghuvanshi, R.S. (2012). Finger millet for food and nutritional security. African Journal of Food Science, 6: 77-84.

Ugwuona, F.U. (2009). Chemical and sensory evaluation of soy-fortified cassava wheat biscuit. Journal of Tropical Agriculture, Food, Environment and Extension, 8(1): 55-59.

Ushakumari, S.R., Shrikantan, L. and Malleshi, N.G. (2004).The functional properties of popped, flaked, extruded and roller dried foxtail millet (Setaria italica). International Journal of Food Science and Technology, 39: 907-915.

\section{How to cite this article:}

Reeta Mishra, Y.D. Mishra, B.P.S. Raghubanshi and Singh, P.P. 2018. A Comprehensive Analysis of Ready to Eat Snack Food. Int.J.Curr.Microbiol.App.Sci. 7(08): 4125-4130. doi: https://doi.org/10.20546/ijcmas.2018.708.429 